\title{
Building a Modern Political Ecology and the Need to Demystify Political Meritocracy
}

\author{
Liu Jingxi 劉京希 \\ Associate Editor of Literature, History and Philosophy, \\ Shandong University, China \\ sdjingxiliu@163.com
}

Translated by Anja Bihler

\begin{abstract}
To construct socialism with Chinese characteristics, advance socialist democracy, and establish a political ecology for socialism with Chinese characteristics, we should devote our efforts toward building a stronger political system and strengthening the rule of law and democracy. Important projects, such as the anti-corruption campaign, mass-line education, or team building for government officials should be guided by the spirit of democracy and the rule of law and proceed in an orderly and regulated manner. Still, voices in support of political meritocracy have become increasingly audible in Chinese political and academic circles, supporting a political phenomenon completely incompatible with the goal of building a socialist democracy. Meritocracy as a political system entails a high degree of uncertainty, unsustainability, and risk and is essentially just a modified version of the rule of man or, to put it differently, the rule of man "2.o." Its fatal weakness is its inability to resolve two fundamental problems related to the legitimacy of political power: Where does power originate, and how can we control it? An important theoretical prerequisite for building a clean political ecology is thus to demystify meritocracy and dispel any popular myths surrounding it.
\end{abstract}

\section{Keywords}

Democracy - political ecology - political legitimacy - political meritocracy - rule of law - rule of man 
A new trend in Chinese politics and academia has emerged that advocates political meritocracy and new authoritarianism. The timing of this political phenomenon is related to the current low ebb in the global wave of democratization and follows the pervasive theme in current Chinese thought and public opinion that promotes traditional culture centered on Confucian theories.

This trend and the voices supporting political meritocracy run counter to the big trends in the development of human society-democracy and the rule of law-and fail to conform to the demands of the socialist democracy that China strives to realize. Moreover, it is harmful for building a clean modern political ecology. The reasons are obvious: the system design of political meritocracy entails a high degree of uncertainty, unsustainability, and risk. Are the anti-rightist campaign, the Great Leap Forward, and the Cultural Revolution [1966-1976] not all logical results of political meritocracy? Our recent history is filled with prominent examples, so we should heed the warning and avoid making similar mistakes.

After rejecting totalitarianism and only thirty-some years of the Reform and Opening-up Policy, voices advocating political meritocracy have emerged because we have not yet fully reflected on the serious flaws of political meritocracy as a system of governance: it perpetuates the rule of man, opposes democracy, and hampers the education of the people. To construct socialism with Chinese characteristics, advance socialist democracy, and establish a political ecology for socialism with Chinese characteristics, we should devote our efforts toward building a stronger political system and strengthening the rule of law and democracy. Important projects, such as the anti-corruption campaign, mass-line education, or team building among government officials, should be guided by the spirit of democracy and the rule of law and proceed in an orderly and regulated manner. Against the backdrop of an era that seeks to advance traditional culture, political meritocracy - as an important part of traditional political culture - is set to make a comeback in both theory and practice. This is a political phenomenon entirely incompatible with the goal of building a socialist democracy. An important theoretical prerequisite for building a clean political ecology is thus to demystify meritocracy and dispel any popular myths surrounding it.

1

Unsurprisingly, current Chinese efforts at building a political culture draw heavily on traditional Chinese thought. The progress and development of any country and its people, especially in the course of modernization, are 
influenced by traditional factors, and its inherent connection with traditional culture is not easily broken. The question of how traditional culture should be preserved and passed on needs to be addressed with a scientific and objective attitude; we cannot completely negate traditional culture one moment and completely embrace it the next. Academic research on political meritocracy should equally maintain such an attitude, which is, however, not the case at present.

The fervor of research on political meritocracy is a typical manifestation of the renaissance of traditional culture, exemplified by Confucian thought, in the political sphere. Because the selection and promotion of men of virtue and talent form the essence of political meritocracy, they offer vigorous public support for Confucian doctrines based on the teachings of Confucius 孔子 [551-479 вСЕ] and Mencius 孟子 [372-289 вСE].

Scholars such as Daniel A. Bell, Bai Tongdong 白娅東, and Wang Guoliang 王國良 are representative of current academic research on political meritocracy. Among them, Daniel A. Bell is a pioneer in theoretical research on modern political meritocracy.

But what is political meritocracy? According to Bell's understanding, the basic idea of meritocracy is that although everyone should be granted equal access to education and the opportunity for political participation, not everyone is endowed with the same aptitude for moral and political decision making. Identifying men of outstanding ability and persuading them to serve in politics is therefore an important task. ${ }^{1}$ It follows that political meritocracy is the idea that a political system is designed with the aim of selecting political leaders with above average ability to make morally informed political judgments. That is, political meritocracy has two key components: (1) the political leaders have above average ability and virtue and (2) the selection mechanism is designed to choose such leaders. ${ }^{2}$

In fact, meritocracy has always existed and advocates for political meritocracy acknowledge that "political meritocracy has been, and continues to be, central to Chinese political culture."3

In China, political meritocracy can be traced back to the times of the Three Sage Kings [mystical age] and the idea of "abdicating in favor of someone worthy” [shanrang zhi 禪讓制] or even further to primitive versions of democracy

1 Daniel Bell [Bei Danning 貝淡寧], “Cong 'Yazhou jiazhiguan' dao 'xianneng zhengzhi' 從“亞洲價值觀, 到·賢能政治' [From 'Asian Values' to 'Political Meritocracy'],” Wen shi zhe 文史哲 [Journal of Literature, History, and Philosophy], no. 3 (2013).

2 Bell, “Xianneng zhengzhi shi ge hao dongxi 賢能政治是個好東西 [Political Meritocracy Is a Good Thing]," Dangdai shijie 當代世界 [Contemporary world], no. 8 (2012).

3 Bell, “Cong Yazhou jiazhiguan dao xianneng zhengzhi," 7. 
in ancient times that championed the ideal that "all under heaven belongs to the people" [tianxia wei gong 天下為公]. At the very least, we can trace the idea to the Western Zhou dynasty西周 [1046-771 BCE], when we find evidence in the Book of Documents [Shangshu 尚書]. ${ }^{4}$ The Duke of Zhou said: "King Wen was able to make the minds of those in the [three high] positions his own, and so it was that he established those regular officers and superintending pastors, so that they were men of ability and virtue." Supposing that political support already existed for the idea of "exalting the virtuous" [shangxian 尚賢] during the Western Zhou and considering that Confucius was known to "follow [the practice] of the Zhou" [congzhou 從周], it is obvious why he also adopted their ideas on meritocracy. As a result, "exalting the virtuous" became an important political proposition in Confucianism that Confucius, Mencius, and Xunzi 荀子 [316-237 BCE] all spoke about at length, in an effort to publicize the idea. 6 "Zhonggong 仲弓, who was serving as a steward for the Ji family, asked the Master about governing. The Master said, first appoint your supervising officials, then overlook their petty faults and promote those who are worthy and talented."7 After the fall of the Qin [221-207 BCE] and Han dynasties [206 BCE-220], political meritocracy manifested itself in various selection mechanisms for political and administrative talent: worthy men could be selected for office directly by the sovereign [zhengpi zhi 征辟制], recommended to the central administration by officials at the local level [chaju zhi 察舉制], ranked and designated for office by impartial judges [jiupin zhongzheng zhi 九品中正制 system of nine ranks and impartial judges], or rise through the imperial examination system [keju zhi 科舉制].

This shows that the special character and essence of political meritocracy are that political leaders and officials at all levels are selected through a set of mechanisms based on their level of education, moral virtue, and ability.

As those advocating political meritocracy have proposed, attempts are currently being made to combine certain aspects of democracy with the basic model of traditional political meritocracy to create a meritocratic system with

4 Ge Quan 葛荃, Quanli zaizhi lixing-shiren chuantong zhengzhi wenhua yu zhongguo shehui 權力宰製理性——人傳統政治文化與中國社會 [Power Dominating Rationality: Literati, Traditional Political Culture and Chinese Society] (Tianjin: Nankai University Press, 2003), 44.

5 Shangshu-Zhoushu一Lizheng. 尚書・周書・立政. Translation based on James Legge, trans., The Sacred Books of China: The Texts of Confucianism, Part I (Oxford: Clarendon Press, 1879), 223.

6 Ge, Quanlizaizhi lixing, 44.

7 Analects-Zilu. 論語-子路. Translation based on Edward Slingerland, Confucius Analects: With Selections from Traditional Commentaries (Indianapolis: Hackett, 2003), 138. 
modern characteristics suited to the conditions of our time. Scholars such as Professor Bai Tongdong at Fudan University and Professor Chen Zuwei 陳祖為 [Joseph C. W. Chan] at Hong Kong University have "argued for a hybrid political regime that combines elements of democracy and meritocracy, with meritocratic houses of government composed of political leaders chosen by such means as examination and performance at lower levels of government (I have also argued for a hybrid regime, with a meritocratic house of government termed the House of Exemplary Persons [xianshiyuan 賢士院]).”

But the very idea of a selection mechanism for talent already reveals that political meritocracy is, at its core, a form of the rule of man. To put it bluntly, those who propagate political meritocracy are doing no more than cloaking political meritocracy in a layer of democracy to make it seem more appealing and modern.

A theoretical proposition inherent to political meritocracy is the assumption that only a talented political elite has the necessary ability, moral foundation, and public-mindedness to manage and govern a country and society. Ordinary people are limited by their education and upbringing and lack the ability and the necessary public spirit to participate in politics. "The basic idea of political meritocracy is that everyone should have an equal opportunity to be educated and to contribute to society and politics, but not everyone will emerge from this process with an equal capacity to make morally informed political judgments and become an outstanding talent." ${ }^{\prime 9}$ Frankly speaking, the essence of political meritocracy is nothing but political elitism. This makes political meritocracy as such entirely incompatible with democracy. Even if those in support of political meritocracy attempt to introduce democratic elements into the meritocratic system, this does not suffice to fundamentally reverse the system's rule-of-man character expressed by merit-based selection and governing elites.

We should also bear in mind that human society continuously advances. Humanity has already advanced from a feudal society of "subjects" to a modern society of "citizens." Unlike in the age of feudalism, it is no longer a small social elite that sustains modern societies but "right holders" universally acknowledged by society. This is to say the present era considers the individual the basic unit of society. Individuals are individuals not only in the moral sense but

8 Bell, "Xianneng zhengzhi shi ge hao dongxi."

9 Bell, Xianneng zhengzhi: weishenme shangxian zhi bi xuanju minzhu zhi geng shihe Zhongguo 賢能政治: 為什麼尚賢制比選舉民主制更適合中國 [The China Model: Political Meritocracy and the Limits of Democracy], trans. Wu Wanwei (Beijing: CITIC Publishing Group, 2016), 21. 
also in the sense of the rights that they possess. This idea of the individual as the basic unit is significant because it respects the freedom, rights, and dignity of each person, not just the freedom, rights, and dignity of the political elites as advocated by political meritocracy.

Despite diverging opinions and controversies surrounding political meritocracy, the issue is not primarily one for academic discussion but, rather, concerns the realities of a political model both influenced and reflected by historic traditions. It essentially raises questions about the type of political system China eventually desires and the general direction of China's future development. After a hundred years of ongoing discussion, all issues surrounding political meritocracy have been sufficiently debated at a purely academic level.

During the age of regional governance, before the birth of the international system, democratic ideas and practices were implemented within regional and national borders and had not yet converged into a global democratic trend. The people lacked a clear sense of their own autonomy or rights and their democratic consciousness was not yet fully developed. If we assume that these factors were conducive to meritocratic practices, it seems oddly out of place to argue for so-called political meritocracy in an era of globalization with the free circulation of information and a surging democratic tide.

2

It is puzzling that political meritocracy has once again entered the political arena in an age of globalization marked by fully developed consciousness of citizenship and a global civil society. Let us list the many queries and request that those in support of political meritocracy provide a convincing and earnest response that can dispel any lingering doubts and suspicions.

First, how do you guarantee that a meritocratic selection process is open and transparent? How do you guarantee that positions are truly open to the public? And how do you guarantee that the power of those appointed to office is properly controlled? These are important standards for evaluating the sustainability of a system's political ecology and issues greatly valued in modern political ecology.

The main reason for raising these matters is the serious malpractice that has occurred during the implementation of political meritocracy in the past. In political meritocracy, the mechanisms for talent selection are neither open nor transparent. Seemingly operating as a black box, the system lacks social persuasiveness and public credibility and produces officials of questionable 
legitimacy. Even though the talent selection process is regulated, the rules and principles are often ignored by powerful institutions or high-ranking individuals because of the rule-of-man qualities inherent in political meritocracy. During the selection and appointment process, personal willpower often transgresses the rules of the system, rendering them powerless to supervise and control the process. This makes it difficult to guarantee that vacant positions are equally open to all. What is more, after taking up their posts, the "worthy and able" will overstep the limits of their power, as is customary in political meritocracy. After the founding of the New China [1949], we continued to practice a modified version of political meritocracy for a long period, because the democratic system had not yet been fully established. The serious problems of the "discretion" and excessive use of political power remained unresolved, and the highest political leader "acted more and more arbitrarily and subjectively, and increasingly put himself above the Central Committee of the [Chinese Communist] Party. The result was a steady weakening and even undermining of the principle of collective leadership and democratic centralism in the political life of the Party and the country."10 Honestly speaking, to attack a political leader personally for acting "arbitrarily and subjectively" seems inappropriate. The attack should, instead, target the meritocratic system whose unscientific design is responsible for such unwanted results.

The second question is related to what we have just discussed: How do you "measure" political meritocracy? If political meritocracy, unlike democratic election processes, cannot be "measured," then how do you guarantee the

10 "Zhongguo gongchandang zhongyang weiyuanhui guanyu jianguo yilai dang de ruogan lishi wenti de jueyi 中國共產黨中央委員會關於建國以來黨的若干歷史 問題的決議 [Resolution on Certain Questions in the History of Our Party since the Founding of the People's Republic of China]," Peking Review, no. 27 (1981): 25. The resolution was adopted by the sixth plenary session of the Eleventh Central Committee of the Chinese Communist Party on June 27, 1981. The quotation is part of an evaluation of the Cultural Revolution and specifically discusses the role of Mao Zedong 毛澤東 [1893-1976]. The full passage reads: “Comrade Mao Zedong's prestige reached a peak and he became arrogant at the very time when the Party was confronted with the new task of shifting the focus of its work to socialist construction, a task for which the utmost caution was required. He gradually divorced himself from practice and from the masses, acted more and more arbitrarily and subjectively, and increasingly put himself above the Central Committee of the Party. The result was a steady weakening and even undermining of the principle of collective leadership and democratic centralism in the political life of the Party and the country. This state of affairs took shape only gradually, and the Central Committee of the Party should be held partly responsible. From the Marxist viewpoint, this complex phenomenon was the product of given historical conditions. Blaming this on only one person or on only a handful of people will not provide a deep lesson for the entire Party or enable it to find practical ways to change the situation." 
fairness of the meritocratic selection mechanisms? Also, how do you guarantee that those selected are indeed "men of virtue and talent"? Political meritocracy attempts to divorce itself from real society and any human considerations and claims that talent selection and promotion are impartial processes based entirely on ability. The system places blind trust in the moral character of those selected and attaches little importance to constructing mechanisms to restrain their power. The criteria and decision-making processes used for selecting and employing talent are highly arbitrary and not quantifiable. What is being created, I am afraid, can only be described as a utopian political meritocracy that does not exist in real politics. Even advocates of political meritocracy must admit this much: During China's feudal age, senior local officials exercised great power over the promotion and recommendation of talent for office, "but the influence of local wealthy families also had a strong effect on the process. Virtuous and talented candidates with a humble family background were not necessarily chosen for recommendation, while those from wealthy families were often appointed despite lack of morals or talent."11 In addition to the appointment of ordinary officials, "candidates for the more important positions were recommended by senior officials at the imperial court and finally decided on by the emperor.... Great Confucian scholars of successive dynasties, such as Zhu Xi 朱喜 [1130-1200], were strongly opposed to the practice of the emperor directly appointing officials according to his own liking. They demanded that the selection of officials strictly follow set procedures. The combined efforts of successive generations of Confucian scholars, however, were not sufficient to effectively prevent the autocratic will of the sovereign from taking precedence. This became the biggest shortcoming of the talent selection process in ancient China." ${ }^{\prime 2}$ If we do not fundamentally modify the basic framework of traditional political meritocracy but, instead, continue to modify and amend the system, how will this new political meritocracy solve the existing problems?

The third question is: How do you guarantee that the selection process draws on a sufficiently large pool of talent? In political meritocracy, only the exam system for lower-level public servants draws on a sufficiently broad range of possible candidates from society at large. The various steps involved in the selection and promotion of high-level talent, however, are carried out

11 Wang Guoliang 王國良, "Rujia xianneng zhengzhi sixiang yu zhongguo xianneng tuiju zhidu de fazhan 儒家賢能政治思想與中國賢能推舉制度的發展 [Confucian Thought on Political Meritocracy and the Development of a Meritocratic Selection System for Office]," Wen shi zhe, no. 3 (2013): 31. 
over successive hierarchical levels from the top down. Here, the number of possible candidates is limited, and the steps and mechanisms involved in the selection process are rarely known to the public. This type of system design inevitably leads to a narrowly defined talent pool. Talent can be drawn only from the bureaucratic and administrative system or affiliated institutions. It is hard to extend the scope to a broader field outside the system, let alone search for candidates from among ordinary people. In the "political meritocracy" of the feudal age, candidates for key positions were normally recommended by important officials at the imperial court. Eventually, the emperor decided whether to appoint a candidate. With only few individuals involved in the selection process and a narrow pool of eligible talent, it was difficult to realize the self-professed goals of political meritocracy, namely, for all people to fulfill their potential and only men of talent and virtue to be appointed for office. Given political meritocracy's top-down system of talent selection that, compared to democracy, lacks the power to mobilize all parts of society and inspire political participation, we might ask: How do you guarantee that the system does not "bury" men of real talent?

The fourth question is, how do you guarantee that those selected by political meritocracy for "being able and virtuous" actually maintain these qualities over time? How do you ensure they use their abilities for the benefit of the people without being carried away by selfish desires, thereby turning corruption into an even more serious problem? How do you ensure that they use their power for the people's advantage, not to advance their subjective goals, or rely on their power to push for major economic, political, and social policies that are divorced from reality, and sacrifice the basic interests of society and the country? In the past, these were the biggest shortcomings of political meritocracy to be castigated by the people. Numerous examples prove time and again that if the "able and virtuous" lack systematic and rigid limitations on their power, the initial impetus to "use the power for the benefit of the people" gradually begins to weaken and eventually turns into a desire "to use the power for their own benefit," to use public office for private gain, and to give in to corruption. There are simply too many painful examples showing that policies based on subjective and surreal ideals of political leaders can sacrifice the collective benefit of a country and the future of a country and its people.

Political meritocracy makes extremely strict demands on the virtue and character of civil servants, sometimes even bordering on the inhumane. Meritocracy seems to have an unhealthy obsession with "moral cleanliness" and demands that politicians strive for moral perfection and continually uphold their best self. But to insist on such stringent standards when searching for political talent can only be described as looking for a needle in a 
haystack. Moreover, the current society no longer resembles that of old but has become far more complex and diverse. Politicians must face a world full of temptations, which, without doubt, further increases the demands on personal cultivation. Because the transmission process of traditional culture represented by Confucian thought was ruptured in China, today's moral cultivation and accomplishment no longer lives up to the standards of antiquity. At this point, without a doubt we have an urgent need for systematic limits on power. Given the present circumstances, where is the moral basis and scientific rationality for advocating political meritocracy that is based merely on moral self-cultivation?

Currently, most people believe that the environment in society is "unclean and improper" and that moral standards have been severely lowered, to the point that they can no longer compare to the standards before China's economic reform period. On the surface, this is, as many have pointed out before, the necessary result of a market economy not yet fully developed and perfected, in which the limits on power are unclear, in which collusion between public officials and businessmen is rampant, and pay-to-play deals are ubiquitous. The most important cause, however, is modern-day political meritocracy and its top-down system for selecting talent that sows the seeds for corruption. If an official sees the opportunity to change the trajectory of his career, he only needs to spend relatively little energy and money to "make a deal" with his superiors and be transferred or promoted accordingly. What limited costs are incurred in the process can easily be passed on to subsidiary departments or companies under his control to pick up the check.

Compared to democracy, on which adequate mechanisms does political meritocracy rely to ensure that "power is placed in a cage of regulations"? 13 Experience shows that we cannot blindly place our hopes in the system to "select and promote political leaders with superior intelligence, social skills, and virtue."14 The risk that political leaders selected in this fashion will make erroneous policy decisions or commit serious mistakes is at least 50 percent. The question we should ask is: through which permanent and reliable method can we prevent this 50 percent risk from materializing? Meritocratic practices have failed to provide a satisfying answer in the past. Political leaders periodically abuse the power with which they were entrusted by society and blindly

13 “Ba quanli guanjin zhidu de longzi li 把權力關進制度的籠子裡 [Placing Power in a Cage of Regulations]" is an idea put forward by the Chinese president Xi Jinping during the second plenary session of the 18th Central Committee of the Chinese Communist Party in early 2013.

Bell, Xianneng zhengzhi, preface. 
pursue political and social policies that are fundamentally flawed, thus seriously delaying social progress. At this point in time, no trace remains of the idea of "virtue." If we insist that virtue continue to play a role, it mostly has the negative effect of confusing people and concealing the reality of those with "ability" manipulating power. Maybe this political system also attempts to "place power in a cage of regulations," but in political meritocracy, power has a persona that is much more powerful and beyond the reach of all regulations. In real politics, the "cage" is eventually nothing more than a tiny "birdcage" and a plaything in the hands of the powerful. Moreover, where political power and authority are highly concentrated in the hands of a select few, those individuals have no intrinsic motivation to establish mechanisms that will restrict their own power, such as constitutional courts or independent systems of judicial review. On the contrary, any type of institution or person holding power has a natural tendency to further consolidate that power; this is a rule virtually set in stone. In political meritocracy, with its high esteem for people of virtue and merit, virtue is considered the only proper way of controlling power, rendering any institutional mechanism to restrain and control power superfluous. Given these facts, it seems nonsensical to expect a highly concentrated, meritocraticstyle power system with a strong rule-of-man character to limit its own right to exercise power. Who would be willing to restrict his own power? As Jo Littler writes in her work, "meritocracy is a description that is both inaccurate and harmful, and that its use legitimizes inequalities of power and privilege through 'claims that are demonstrably false."'15 We need to slowly break down political authority and work toward a separation of powers, slowly progressing toward democratization. This is the only way to create a suitable political environment for building a legal system and procedures that can limit the highest power and authority. ${ }^{16}$

The fifth question is closely connected to these issues. Political meritocracy as a political system and any type of meritocratic practices have always been closely connected to the idea of privilege. On the one hand, political meritocracy defies rationality and holds politicians to an unrealistic "sage"like moral standard, as if they were saints or paragons of virtue. On the other hand, political meritocracy also grants politicians a multitude of material

15 Jo Littler, "Meritocracy as Plutocracy: The Marketising of 'Equality' under Neoliberalism," New Formations, nos. 80-81 (2013): 55 .

16 Jiang Feng 姜峰, “Sifa shencha de zhengzhi baoxian lun 司法審查的政治保險論 ['Political Insurance' Theory of Judicial Review]," Renda falü pinglun 人大法律評論 [Renmin University Law Review], no. 2 (2016). 
benefits, even operating a "special supplies" system. ${ }^{17}$ With detailed regulations deemed unsuitable to be made public, the system grants politicians a range of privileges that far exceed the treatment accorded to ordinary citizens. Is this not what makes political meritocracy so self-contradictory and leaves observes bewildered? Until now, the supporters of political meritocracy have failed to resolve the question of privileges of "public servants" that necessarily result from the lack of oversight in political meritocracy. In this regard, democratic and meritocratic systems are hugely different. Some have argued the more modest the lifestyle of national leaders after leaving office, the lower a country's level of corruption and vice versa. After his retirement, the former Japanese prime minister Tomiichi Murayama 村山富市 was given no guards, secretary, or servants and lived on a pension of several hundred thousand yen as a former member of the Japanese Diet. He did not receive any family allowance or money for books or transportation. In case of illness, he was covered by an ordinary health insurance policy for Japanese citizens and had to pay onethird of the expenses himself. ${ }^{18}$ His example should suffice to make the point.

The sixth and final question is: How do you realize the integration of political meritocracy and democracy? Following the reasoning of those who design its style of governance, we should add democratic features to the basic framework of political meritocracy. Given political meritocracy's Confucian tradition and the continuous improvement and refinement of its talent selection process in contemporary China, "it can be developed into a superior democratic system with Chinese characteristics." ${ }^{19}$ But one question remains: the main characteristics of Confucian political meritocracy are talent selection and examination systems, based on a top-down selection process. How do you reconcile this with the defining features of socialist democracy: a bottom-up election system and the people as masters of their own affairs? Even if you forcibly combine the two, how can you guarantee that the systems are sufficiently compatible?

In clear contrast to political meritocracy, the way in which democratic systems are designed guarantees a broad selection of talent without "burying" men of real talent and virtue. Through the separation of politics and law, and the corresponding mechanisms of checks and balances, democracies clarify, to the maximum degree possible, the limits to the exercise of power. This

17 In the Chinese context, tegong 特供 [special supplies] refers to a long-existing supply system of organic and safe foodstuffs for the political elite.

18 Xu Jingbo 徐靜波, Riben ren de huofa 日本人的活法 [The Japanese Way of Life] (Beijing: Huawen chubanshe, 2017), 5 .

19 Wang, "Rujia xianneng zhengzhi sixiang." 
prevents policy makers from ignoring the basic interests of the majority, willfully deciding on policy matters according to their own desires.

As can be seen, political meritocracy, is essentially nothing but a modified version of the rule of man or, to put it differently, the rule of man "2.0" - a far cry from modern democracy.

General Secretary Xi Jinping 習近平 first mentioned the idea of "political ecology" [zhengzhi shengtai 政治生態] at the sixteenth collective study session of the Politburo on June $30,2014 .^{20}$ He spoke about strengthening party building and the need to create a positive political environment, that is, a clean political ecology. He continued to stress the importance of purifying the political environment on several different occasions, hoping to create "ranks of efficient and moral party members and public officials, convenient and effective control mechanisms, and a clean and nurturing political ecology that gives no room for unhealthy trends and evil practices." ${ }^{21}$ From this, we can infer the epochal significance of a clean political ecology for political system building. In times that value and promote traditional culture, the voices in support of political meritocracy contradict the express goal of establishing a clean political ecology. An important prerequisite for building a clean political ecology is therefore to demystify the idea of political meritocracy.

From the perspective of the study of political ecology, a modern political system with a clean political ecology means a political system that can protect the freedom and legitimate rights of its citizens, safeguard public interests, curb abuse of power, and, at the same time, provide public efficiency. To successfully cultivate this type of modern political system, we must ensure the necessary limits on political power and contain it within the boundaries set by social justice and citizens' rights. If we use these expectations to think about political meritocracy, it becomes obvious that political meritocracy touches

20 “Guanyu 'zhengzhi shengtai' Xi Jinping dou shuole shenme 關於“政治生態,習近 平都說了什麼 [What Did Xi Jinping Say about 'Political Ecology'],” Xinhua Wang 新華網 [Xinhua Net], November 3, 2015, http://www.xinhuanet.com/politics/2015-03/11/ c_1114601310.htm.

21 “Xi Jinping zhuchi zhaokai shan'ganning geming laoqu tuopin zhifu zuotanhui ceji 習近平主持召開陝甘寧革命老區脫貧致富座談會側記 [Sidelights on Xi Jingping Moderating the Opening of the Symposium on Poverty Alleviation for the Shaan-GanNing Old Revolutionary Region]," Xinhua Wang, February 16, 2015, http://www.xinhuanet. com/politics/2015-02/16/c_1114394435.htm. 
upon a range of issues, such as protecting the freedom and legitimate rights of citizens, preserving public interests, preventing any form of abuse of power or infringements of the basic interests of society. Overall, the record of meritocratic practices in the past has not been ideal.

Irrespective of whether we look at the functionality of the system design or historical examples of meritocratic practices, the natural evolution of society and humanity will eventually result in democracy. Democracy clearly satisfies the requirements of a clean political ecology and conforms more fully to the history and future trends of human development. Democracy, without a doubt, represents the future development of human political culture.

Traditional political meritocracy is based on the rationality of the individual, which is naturally limited. Based on personal preferences and drawing on their positions of authority, political decision makers manage the affairs of the people in a top-down manner. Modern democracy, by contrast, aggregates the rationality of all individuals in society. In a democratic system, the common people draft the "rules of the game" and entrust representatives to handle the affairs of the community in adherence with all relevant laws and regulations. In political meritocracy, power is granted by the highest leaders, while democratic power comes from the people. With political meritocracy, power operates in only one direction from the top down, whereas democratic systems allow for vertical interaction of power in both directions. Democracy is thus more scientific and humane and provides a more sustainable political ecology because of various corrective mechanisms built into the system. This is why modern societies worship, trust, and pursue democracy.

From a metaphysical perspective, people ordinarily think of democracy as a form of political system with elections as the defining feature. Without elections, there is no democracy. Democracy, however, is also based on a number of additional factors. Democracy also means freedom, justice, a system of accountability, checks and balances, a state of equilibrium, and all processes and procedures necessary to ensure these values. Political meritocracy, however, lacks all of these. From the perspective of political ecology, democracy remains the political form best suited to the demands of social ecology.

This rings true because a political system founded on democratic ideas and regulations is an open system. Its openness is displayed in two ways: the system is open to both the outside and the inside. Open to the outside means that the emergence and behavior of political leaders are the result of interaction between the political system and the society in which it operates. The system provides for certain modes of interaction, such as voting, hearings, responses to inquiries, supervision, and other democratic features, all of which are dependent on the political system's openness to society. At the same time, 
and through a continuous process of opening up, the political system accepts supervision and control by society and manages to control and balance the flow of goods, power, and information between the system and the environment. Being open to the inside means that a democratic system encourages mutual supervision and control between all its subsystems and important institutions. Democratic systems are built for and defined by internal conflict, debate, and compromise. Its inefficient, controversial, and tedious policymaking process seems completely incompatible with the rapid rhythm of modern life. However, only such a prudent policy-making process, marked by a multitude of choices and intense debate, can prevent seriously flawed policy decisions and make a society develop more efficiently. In comparison, a system of centralized state power, symbolized by political meritocracy, appears to be highly efficient at first sight. The policy-making process, however, entails the risk of major policy errors that have the potential to delay the development of society. Democratic systems that are based on the principle of openness to the inside fare immeasurably better in this regard.

Looking back on China's long history of political development, what we lack least is political meritocracy. In essence, political meritocracy is a form of the rule of man that takes individual members of the elite as its political leitmotif. A notable characteristic of political meritocracy is the leading figures' extreme veneration for individual willpower and agency and for individual power divorced from actual conditions and any type of restrictions. This implies that political meritocracy opposes any form of supervision or limitation, the separation of powers, and eventually also democracy and the right of citizens to equal political participation. Some of the advocates for political meritocracy have proposed merging meritocratic and democratic practices and "continuously improving and perfecting the meritocratic selection process, by employing effective measures to avoid any drawbacks or pernicious habits of China's traditional talent selection mechanisms. If we learn from the strong points of the talent selection and promotion systems in today's world and gain concrete experience through actual practice, we can gradually create a superior democratic system with Chinese characteristics."22 Eventually, however, this must remain wishful thinking.

Political meritocracy relies on the personal ability and moral integrity of its "righteous rulers and virtuous ministers," while lacking an effective system to control their power. History has repeatedly shown that no matter how the concrete shape varies, political meritocracy will eventually develop into a form of the rule of man, centralized state power, erroneous policy making, 
and an unenlightened population. In times when people were still "subjects" of feudal rulers and lacked a clear awareness of their own rights, political meritocracy's absolute rule persisted. In our modern age, however, people perceive themselves as individuals, and their democratic consciousness has mostly been awakened. Because political meritocracy has no power to balance or resolve the inherent conflicts that necessarily exist between those in power, on the one hand, and the citizens and their institutions, on the other hand, the actual probability that political meritocracy will be implemented has greatly declined. Even supporters of political meritocracy admit to this point:

The success of meritocracy in China is obvious: China's rulers have presided over the single most impressive poverty alleviation achievement in history, with several hundred million people being lifted out of poverty. Equally obvious, however, some problems in China-corruption, gap between rich and poor, environmental degradation, abuses of power by political officials, overly powerful state-run enterprises that skew the economic system in their favor-seem to have worsened during the same period the political system has become meritocratic. ${ }^{23}$

But even if some advocates of political meritocracy have recognized the power of democracy in solving these problems, they stubbornly continue to express their support:

Part of the problem is that China lacks democracy at various levels of government that could help to check abuses of power and provide more opportunities for political expression by marginalized groups. But part of the problem is also that political meritocracy has been insufficiently developed in China. The system has become meritocratic over the last three decades or so, but it can and should become more meritocratic in the future. ${ }^{24}$

The most fatal weakness of political meritocracy is that it fails to resolve two fundamental problems related to the legitimacy of political power: the source and limitation of power. Objectively speaking, implementing political meritocracy will not yield satisfactory results. Modern political theory and practice have always paid close attention to issues such as the source and limitation of power, proof of legitimacy of a political system, and its degree of ecologization.

23 Bell, "Cong yazhou jiazhiguan dao xianneng zhengzhi," 10.

24 Ibid. 
Modern political theory and practice have repeatedly shown that only democracy, and political and legal systems based on democratic ideals, can provide a wholesale and systematic solution to the two fundamental problems directly related to the issue of legitimacy: where does power originate, and how do we control it? Only democracy can be an inexhaustible source of trust in a political system. "Power needs legitimacy. Only power that has won approval is truly sustainable and effective. This type of legitimacy can only derive from democracy."25

Nothing can be truly perfect, and any differences in quality must be relative; this also applies to political systems. Democratic systems equally have flaws, such as the tyranny of the majority, which democracy needs to control. From antiquity until today, the question of the most suitable political system has frequently been posed in the political life of various societies. Why do most societies eventually move toward a democratic system of government? One important reason is that political life in any society is filled with differences, conflict, and contradictions, compelling people to search for a more systematic way to resolve them. Several thousand years of political practice have shown, time and again, that democracy offers the best mechanisms for resolving discrepancies, conflicts, and problems of any kind. Only a democratic system can successfully maximize the common interests of all citizens and turn the protection of the majority's interests from an empty promise into a reliable political principle. To go one step further, the essential meaning of democracy is that it creates a win-win situation for both the majority and the minority in society. Democracy will not sacrifice the legitimate interests of the minority in defiance to the will of the majority. Otherwise, democracy would, without a doubt, be nothing but an autocracy of the majority.

The crux of the matter is, how do we guarantee that democracy does not move in an unwanted direction? Democracy is a political system that has been shaped under strenuous efforts and through countless practice. This is especially true for modern democracies, which represents an even greater achievement. When democratic systems were designed, those responsible for drafting its rules already thought about mechanisms to prevent corruption. That is to say, democratic systems already contain elements of self-restriction and self-supervision. In this sense, the rules restricting a democratic system

25 Zhang Moning 張墨寧, "Yi dangnei minzhu gaibian zhengzhi shengtai-zhuanfang zhongyang dangxiao dangjian jiaoyanbu zhuren Wang Changjiang jiaoshou 以黨內民主 改變政治生態——專訪中央黨校黨建教研部主任王長江教授 [Using Inner-Party Democracy to Change Political Ecology: An Interview with Professor Wang Changjiang, Director of the Party Building Teaching and Research Department at the Central Party School]," Nanfeng chuang 南風窗 [South Reviews], no. 21 (2014). 
are inherent. This is the essence of democracy. But a good democratic system does not automatically produce good democratic results. A democratic system may operate effortlessly in one country and with one people but produce catastrophic results in another. Not every system works the same way in all environments. For a democratic system to produce satisfactory results, it is important to lay a solid foundation. In addition, the results also hinge on the degree to which the people actually make use of the control mechanisms available to them. To turn democracy's inherent control mechanisms into a requirement for political ecology fully accords with the political values expressed by the theory of political ecology. At present, a democratic system has two options for realizing supervision and control: first, through the separation of powers within the system, realizing mutual control between the numerous systems and key elements within it; second, through opening up and broad political participation that establishes communication channels and feedback mechanisms between the political system and society, thereby realizing a form of outside control. We need to establish an ecological relation between the numerous systems and key elements within a political system, while, at the same time, building communication channels and control mechanisms connecting the political system to its environment. In this way, we can successfully contain any democratic tendencies to overstep the limits of power and turn democracy into an "ecologized" political mechanism. We can now conclude that any democratic system that conforms to the demands of ecology is a democratic system with restrictions and limitations. ${ }^{26}$

In short, political meritocracy has a vertical responsibility system that operates upward one level of hierarchy at a time, while democracy has a vertical responsibility system that operates downward in the same manner. China's current and future use of political meritocracy will rely more on democratic ideas than on political meritocracy. Compared to political meritocracy, the current trends of democracy and socialization of power develop in roughly the same direction. In the words of Thomas Jefferson, the third president of the United States, entrusting the people with the highest power in society is the safest option. Assuming that the people lack sufficient knowledge to control this power prudently, we should give them the necessary knowledge, instead of wresting power from their hands. ${ }^{27}$ We should bear in mind that

26 Liu Jingxi 劉京希, Zhengzhi shengtai lun:zhengzhifazhan de shengtaixue kaocha 政治生 態論: 政治發展的生態學考察 [Political Ecology Theory: Observations on the Ecology of Political Development] (Jinan: Shandong daxue chubanshe, 2007).

27 Thomas Jefferson, The Writings of Thomas Jefferson (Washington, DC: Lipscomb and Bergh, 1903-1904), 15: 278. 
the basic political development goal of socialism is socialist democracy and not political meritocracy. China is currently attempting to build a socialist democracy with Chinese characteristics, which constitutes one of the most important core values of socialism. Only if socialist democracy is further developed and perfected will we be able to broaden our talent selection process and to systematically limit political power, thereby preventing corruption and safeguarding civil rights. Only a developed socialist democracy will allow us to build and maintain a clean political ecology and environment. Political meritocracy, however, is clearly at odds with these goals and requirements.

\section{Works Cited}

Bell, Daniel [Bei Danning 貝淡寧]. “Cong 'Yazhou jiazhiguan' dao 'xianneng zhengzhi' 從“亞洲價值觀' 到 ‘賢能政治' [From 'Asian Values' to 'Political Meritocracy'].” Wen shizhe 文史哲 [Journal of Literature, History and Philosophy], no. 3 (2013): 5-11.

Bell, Daniel. “Xianneng zhengzhi shi ge hao dongxi 賢能政治是個好東西 [Political Meritocracy Is a Good Thing]." Dangdai shijie 當代世界 [Contemporary world], no. 8 (2012): 5-7.

Bell, Daniel. Xianneng zhengzhi: weishenme shangxian zhi bi xuanju minzhu zhi geng shihe Zhongguo 賢能政治: 為什麼尚賢制比選舉民主制更適合中國 [The China Model:Political Meritocracy and the Limits of Democracy]. Translated by Wu Wanwei. Beijing: critic Publishing Group, 2016.

Ge Quan 葛荃, Quanli zaizhi lixing-shiren chuantong zhengzhi wenhua yu zhongguo shehui 權力宰製理性一士人傳統政治文化與中國社會 [Power Dominating Rationality: Literati, Traditional Political Culture and Chinese Society]. Tianjin: Nankai University Press, 2003.

“Guanyu 'zhengzhi shengtai' Xi Jinping dou shuole shenme 關於政治生態習近平 都說了什麼 [What Did Xi Jinping Say about Political Ecology?].” Xinhua Wang 新華網 [Xinhua Net], November 3, 2015. http://www.xinhuanet.com/politics/201503/11/c_1114601310.htm.

Jefferson, Thomas. The Writings of Thomas Jefferson, vol. 15. Washington, DC: Lipscomb and Bergh, 1903-1904.

Jiang Feng 姜峰. “Sifa shencha de 'zhengzhi baoxian lun' 司法審查的“政治保險論” ['Political Insurance' Theory of Judicial Review].” Renda falü pinglun 人大法律評論 [Renmin University Law Review], no. 2 (2016): 445-463.

Legge, James, trans. The Sacred Books of China: The Texts of Confucianism, Part I. Oxford: Clarendon Press, 1879 .

Littler, Jo. "Meritocracy as Plutocracy: The Marketising of 'Equality' Under Neoliberalism." New Formations, nos. 80-81 (2013): 52-72. 
Liu Jingxi 劉京希. Zhengzhi shengtai lun: zhengzhi fazhan de shengtaixue kaocha 政治生態論: 政治發展的生態學考察 [Political Ecology Theory: Observations on the Ecology of Political Development]. Jinan: Shandong daxue chubanshe, 2007.

Slingerland, Edward, trans. Confucius Analects: With Selections from Traditional Commentaries. Indianapolis: Hackett, 2003.

Wang Guoliang 王國良. "Rujia xianneng zhengzhi sixiang yu zhongguo xianneng tuiju zhidu de fazhan 儒家賢能政治思想與中國賢能推舉制度的發展 [Confucian Thought on Political Meritocracy and the Development of a Meritocratic Selection System for Office]." Wen shizhe, no. 3 (2013): 24-31.

"Xi Jinping zhuchi zhaokai shan'ganning geming laoqu tuopin zhifu zuotanhui ceji 習近平主持召開陝甘寧革命老區脫貧致富座談會側記 [Sidelights on Xi Jinping Moderating the Opening of the Symposium on Poverty Alleviation for the ShaanGan-Ning Old Revolutionary Region]." Xinhua Wang, February 16, 2015. http://www .xinhuanet.com/politics/2015-02/16/c_1114394435.htm.

Xu Jingbo 徐靜波. Riben ren de huofa 日本人的活法 [The Japanese Way of Life]. Beijing: Huawen chubanshe, 2017.

Yang Bojun 楊伯峻. Lunyu yizhu 論語譯注 [Translation and Commentary on the Analects]. Beijing: Zhonghua Book Company, 2002.

Zhang Moning 張墨寧. "Yi dangnei minzhu gaibian zhengzhi shengtai-zhuanfang zhongyang dangxiao dangjian jiaoyanbu zhuren Wang Changjiang jiaoshou 以黨內民主改變政治生態—專訪中央黨校黨建教研部主任王長江教授 [Using Inner-Party Democracy to Change Political Ecology: An Interview with Professor Wang Changjiang, Director of the Party Building Teaching and Research Department at the Central Party School]." Nanfeng Chuang 南風窗 [South Reviews], no. 21 (2014): $45-47$.

"Zhongguo gongchandang zhongyang weiyuanhui guanyu jianguo yilai dang de ruogan lishi wenti de jueyi 中國共產黨中央委員會關於建國以來黨的若干歷史問題的決 議 [Resolution on Certain Questions in the History of Our Party since the Founding of the People's Republic of China]." Peking Review, no. 27 (1981): 10-39.

Zhou Bingjun 周秉鈞, comm. Shangshu 尚書 [Book of Documents]. Changsha: Yuelu Press, 2001. 